\title{
Preface \\ Context and importance of biochar research
}

\author{
Beáta Emöke Madari(1) Claudia Maria Branco de Freitas Maia(2), Etelvino Henrique Novotny ${ }^{(3)}$ \\ (1)Embrapa Arroz e Feijão, Caixa Postal 179, CEP 75375-000 Santo Antônio de Goiás, GO, Brazil. E-mail: madari@cnpaf.embrapa.br \\ (2)Embrapa Florestas, Caixa Postal 319, CEP 83411-000 Colombo, PR, Brazil. E-mail: claudia.maia@cnpf.embrapa.br ${ }^{(3)}$ Embrapa Solos, \\ Rua Jardim Botânico, 1.024, CEP 22460-000 Rio de Janeiro, RJ, Brazil. E-mail: etelvino@cnps.embrapa.br
}

In the context of global warming, major changes are expected in the worldwide energy matrix in the near future. Biomass, a renewable source, as a raw material for energy production, is fundamental in this process.

By definition, biochar is any source of biomass previously heated in the absence or at low concentrations of oxygen with the purpose of application to the soil (Maia et al., 2011). The production of biomass for energy (biofuels) requires, above all, soil resources, in terms of occupied land and soil productivity. There are different ways of producing energy from biomass, and the resulting biochar may vary in its physical and chemical composition depending on the kind of biomass and on the conditions of pyrolysis. The technologies that produce biochar as the main product or byproduct of a pyrolysis process are the only ones, among the available biofuel technologies, that may contribute to the improvement or maintenance of soil properties, and, therefore, to the sustainable production of energy and food.

Although it may take until 2020 for pyrolysis technologies to reach a large scale (Inman, 2012), they have the potential to impact sustainable soil management on regional levels. The contribution of biochar as a soil amendment is currently being assessed as to two main aspects. One is related to its potential to enhance the productivity of agricultural systems and to combat land degradation by improving soil physical, biological, and chemical properties (Kookana et al., 2011). The other is its contribution to carbon sequestration, as it contains carbon in stable forms and, consequently, with a longer permanence in the soil (Santos et al., 2012).

However, research on biochar is relatively new, when compared to the age of its inspiration, the "terra preta de índios" - anthropogenic dark earth (ADE) of Amazonia. More organized research on
ADE from an agricultural point of view started in early 2000. Biochar research for agricultural purposes is even more recent. Therefore, critical information is still needed for a scientifically based and safe use of biochar as a soil amendment. One valuable attempt to provide standards for biochar itself and to evaluate biochar-to-soil properties has recently been made by the International Biochar Initiative, which provided product definition and specification guidelines (International Biochar Initiative, 2012). However, the safe use of biochar in agriculture and its effects on the environment demand further transdisciplinary studies on, for example, the possibility of producing biochar with desired properties for specific purposes and its characterization - including any potential toxicity, preferably in long-term field trials - to confirm its real agronomic and environmental effects and economic feasibility.

This thematic issue of Pesquisa Agropecuária Brasileira contains nine original papers, one scientific note, and two special collaborations that were presented at the $3^{\text {rd }}$ International Biochar Conference in Rio de Janeiro, RJ, Brazil, September 9-12 $2^{\text {th }}, 2010$. This conference was organized by Embrapa Solos and was promoted by the International Biochar Initiative (IBI), a nonprofit organization committed to sustainable biochar production and use. The papers of this Issue provide a clear contribution to the advancement of our understanding on the characteristics of biochars from different origins, the methods for its characterization, the chemical and physical behavior of biochar in soils, and its potential environmental impacts, as well as its agronomic performance. Two collaborations address the environmental risk of biochar application to soils and issues related to certification. 


\section{References}

INMAN, M. News feature: cooking up fuel. Nature Climate Change, v.2, p.218-220, 2012.

INTERNATIONAL BIOCHAR INITIATIVE. Standardized product definition and product testing guidelines for biochar that is used in soil. 2012. Available at: $<$ http://www. biochar-international.org/sites/default/files/Guidelines_for Biochar_That_Is_Used_in_Soil_Final.pdf>. Accessed on: 31 May 2012.
KOOKANA, R.S.; SARMAH, A.K.; VAN ZWIETEN, L.; KRULL, E.; SINGH, B. Biochar application to soil: agronomic and environmental benefits and unintended consequences. Advances in Agronomy, v.112, p.103-143, 2011.

MAIA, C.M.B.F.; MADARI, B.E.; NOVOTNY, E.H. Advances in biochar research in Brazil. Dynamic Soil, Dynamic Plant, v.5, p.53-58, 2011.

SANTOS, F.; TORN, M.S.; BIRD, J.A. Biological degradation of pyrogenic organic matter in temperate forest soils. Soil Biology and Biochemistry, v.51, p.115-124, 2012. 